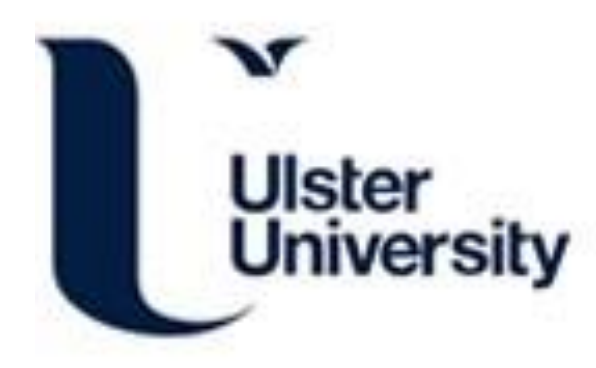

\title{
The GAA and revolutionary Irish politics in late nineteenth- and early twentieth-century Ireland
}

Hassan, D., \& McGuire, A. (2015). The GAA and revolutionary Irish politics in late nineteenth- and early twentieth-century Ireland. Sport in Society, 19(1), 51-61. https://doi.org/10.1080/17430437.2015.1038919

Link to publication record in Ulster University Research Portal

\section{Published in:}

Sport in Society

Publication Status:

Published (in print/issue): 23/06/2015

DOI:

10.1080/17430437.2015.1038919

\section{Document Version}

Publisher's PDF, also known as Version of record

\section{General rights}

Copyright for the publications made accessible via Ulster University's Research Portal is retained by the author(s) and / or other copyright owners and it is a condition of accessing these publications that users recognise and abide by the legal requirements associated with these rights.

\section{Take down policy}

The Research Portal is Ulster University's institutional repository that provides access to Ulster's research outputs. Every effort has been made to ensure that content in the Research Portal does not infringe any person's rights, or applicable UK laws. If you discover content in the Research Portal that you believe breaches copyright or violates any law, please contact pure-support@ulster.ac.uk. 
This article was downloaded by: [Ulster University Library]

On: 30 June 2015, At: 01:23

Publisher: Routledge

Informa Ltd Registered in England and Wales Registered Number: 1072954 Registered

office: Mortimer House, 37-41 Mortimer Street, London W1T 3J H, UK

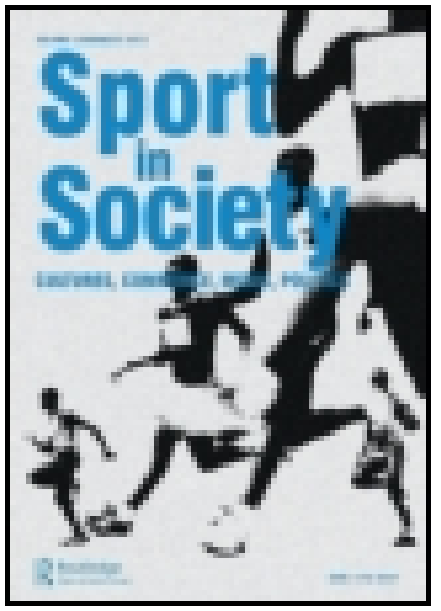

\section{CrossMark}

\section{Sport in Society: Cultures, Commerce, Media, Politics}

Publication details, including instructions for authors and subscription information:

http:// www.tandfonline.com/loi/fcss20

\section{The GAA and revolutionary Irish politics in late nineteenth- and early twentieth-century Ireland}

\author{
David Hassan ${ }^{\text {a }} \&$ Andrew McGuire ${ }^{a}$ \\ a School of Sport, University of Ulster, J ordanstown, UK \\ Published online: 23 J un 2015.
}

To cite this article: David Hassan \& Andrew McGuire (2015): The GAA and revolutionary Irish politics in late nineteenth- and early twentieth-century Ireland, Sport in Society: Cultures, Commerce, Media, Politics, DOI: 10.1080/ 17430437.2015.1038919

To link to this article: http:// dx. doi.org/ 10.1080/ 17430437.2015. 1038919

\section{PLEASE SCROLL DOWN FOR ARTICLE}

Taylor \& Francis makes every effort to ensure the accuracy of all the information (the "Content") contained in the publications on our platform. However, Taylor \& Francis, our agents, and our licensors make no representations or warranties whatsoever as to the accuracy, completeness, or suitability for any purpose of the Content. Any opinions and views expressed in this publication are the opinions and views of the authors, and are not the views of or endorsed by Taylor \& Francis. The accuracy of the Content should not be relied upon and should be independently verified with primary sources of information. Taylor and Francis shall not be liable for any losses, actions, claims, proceedings, demands, costs, expenses, damages, and other liabilities whatsoever or howsoever caused arising directly or indirectly in connection with, in relation to or arising out of the use of the Content.

This article may be used for research, teaching, and private study purposes. Any substantial or systematic reproduction, redistribution, reselling, loan, sub-licensing, systematic supply, or distribution in any form to anyone is expressly forbidden. Terms \& 

and-conditions 


\title{
The GAA and revolutionary Irish politics in late nineteenth- and early twentieth-century Ireland
}

\author{
David Hassan* and Andrew McGuire \\ School of Sport, University of Ulster, Jordanstown, UK
}

\begin{abstract}
The argument outlined in this article builds on the recent detailed historiography of the role of the Gaelic Athletic Association (GAA) around the turn of the twentieth century in Ireland. In the minds of some persuasive authors, the organization exercised an important supportive role in the expression of physical force Irish Republicanism and was therefore a not insignificant player in the activities of bodies expressly committed to this course of action. Yet others, such as the scholar William Murphy, have claimed this interpretation of the GAA's role is wholly overstated and instead it contained within its ranks members who, entirely coincidentally, were also involved in a range of similar entities at that time and were therefore committed to the cause of Irish sovereignty in a relatively benign form. In other words, the GAA offered a useful setting in which prominent Irish nationalists could hone their organizational skills rather than operating as a body that, in any coherent fashion, constituted an active agent in the promotion of an aggressive form of Irish nationalism during this period. By profiling the lived experiences of a select number of prominent GAA personalities, it is possible to illustrate this important distinction and establish the precise role of the association in those seminal decades either side of the turn of the twentieth century.
\end{abstract}

\section{Introduction}

When the Gaelic Athletic Association (GAA) was founded in 1884 by Michael Cusack, he sought the patronage of three prominent Irishmen. The first was Archbishop of Cashel Thomas Croke, courted by Cusack because of the respect the population at large had for him and the central role of the Catholic Church in Irish life. Second was Charles Stuart Parnell, leader of the Irish Parliamentary Party (IPP), the face of constitutional politics at the time. The third was Michael Davitt, founder of the National Land League (NLL). Archbishop Croke was a strong supporter of the work of both Parnell and Davitt. The political views of the three original patrons of the GAA set the early tone for the leanings of the organization as a whole.

As the GAA grew in both numbers and reach, the Irish Republican Brotherhood (IRB) sought to influence the path the Association was to take and counter the influence of the IPP and NLL. Two of the seven men at the founding meeting of the GAA - John Wyse Power and J.K. Bracken - were known to be IRB members (de Búrca 2000). Wyse Power eventually would head up the Dublin County Board. Another member of the Brotherhood, P.T. Hoctor from Tipperary and an active organizer of the GAA in County Clare, would be elected Vice-President of the GAA at its general meeting in 1886. After his election, Hoctor extended an invitation to a fourth patron, this being the Fenian leader John O'Leary (de Búrca 2000).

The next general meeting held in 1887 saw the Fenian P.N. Fitzgerald elected Secretary of the GAA. A contingent of Catholic priests, led by Father Scanlan from

*Corresponding author. Email: d.hassan@ulster.ac.uk 
Nenagh, opposed the nomination of Fitzgerald on the grounds that he being an IRB Official would 'give a very questionable appearance to the outside public' (Mandle 1987, 50). For the next two years, the GAA operated with IRB members as high-ranking officials. During this period, the GAA came under intense scrutiny from the authorities, particularly the Royal Irish Constabulary (RIC), and a report entitled 'The Political Aspect of the Gaelic Athletic Association' was compiled. This same report concluded that two points of contention were deemed to show the 'true character' of the GAA as far as the British Government was concerned - the refusal of uniformed members of the RIC and Army to be allowed join the Association and the appearance of uniformed GAA members at demonstrations of the National League (Dublin Castle Records).

This period of IRB control and the subsequent invoking of the name of the GAA in Irish nationalist politics has been used by several historians, most prominently Marcus de Búrca in his publication The Story of the GAA and W.F. Mandle in The Gaelic Athletic Association \& Irish National Politics, as apparent evidence of the active GAA contributions made towards the ultimate goal of Irish independence. Mandle went so far as to say that 'it is arguable that no organization had done more for Irish nationalism than the GAA - not the IRB ... not the Gaelic League ... not the Irish Parliamentary Party ... not even Sinn Féin' (Mandle 1987, 221).

Around the same time as Mandle and de Burca were advancing their views, David Fitzpatrick argued from a different perspective in his paper 'The Geography of Irish Nationalism, 1910-1921'.

Less overtly political bodies such as the Gaelic League, Volunteers, and GAA represented groups united in their professed enthusiasm for language, games or mock bloodsports. No Irish organisation outside of Ulster could win mass support without proclaiming it's nationalism; but it had also to defend or promote the interests of some clearly defined group or groups. (Fitzpatrick 1978, 134)

It was not the aim of the GAA to be actively revolutionary, but rather a product of the times that necessitated at least an outwardly nationalistic stance with which to court the Irish public and gain their acquiescence. With this view in mind, the GAAs seeming involvement in the Irish nationalist movement is not one of outward revolutionary fervor, but rather one of necessary self-preservation.

A new wave of scholarship, led by historians such as William Murphy, has built on Fitzpatrick's earlier work and placed the established view of the GAA during this period under scrutiny. Indeed Murphy has argued that 'the association's vulnerability and the limits of its influence in a period when nationalism realized revolutionary change are now evident' (Murphy 2009, 76). With a few test cases to illustrate its argument, this article will look to further explore and enhance Murphy's characterization of the GAA, not as an active player in the case for Irish independence, but rather merely constituting the 'playground of the revolution' where those who would go on to lead the rebellion could hone their skills.

Examples showing how revolutionary leaders were able to gain experience and training within the ranks of the GAA, which served them in their work towards gaining Ireland's independence, will therefore be considered. Some attention is paid to the actual events of Easter Week 1916 as it pertains to the GAA, but the uprising itself is not covered in great depth as this has formed the central tenet of many other excellent works and indeed falls outside the scope of this analysis. To begin with, in order to refute the historical point of view concerning the supposed revolutionary role of the GAA that remained dominant for a considerable period of time, it is necessary to understand how this belief first emerged then evolved. Thus, an appreciation of the origins of this viewpoint is 
necessary to properly refute its assertions, which are considered in more depth later in this essay.

\section{A wider role for the GAA}

By the early 1900s, the GAA had been through several attempts by various nationalist groups to co-opt its power structure for their own ends, with some attempts proving more successful than others. As John O'Beirne Ranelagh put it in his work A Short History of Ireland, 'from 1887 onwards, the GAA was regarded by the Special Branch of the RIC as an adjunct of the physical force national movement, and its activities were regularly reported (as such)' (Ranelagh 1983, 153). For the next 30 years, the RIC had informants inside GAA clubs and would follow members to and from its meetings. In 1910, Mr John O'Donnell, M. P. for Mayo South, questioned Augustine Birrell, Chief Secretary of Ireland, about the police allegedly following GAA members in County Galway. O'Donnell accused the police of having detectives pursue members at meetings in Athenry and 'to report to local police stations the names of persons who attend such meetings' (House of Commons 1910). Further, it was suggested, that the president of the county board, Tom Kenny, and other officials were even followed as they went to Dublin on GAA business. O'Donnell reiterated the position of the GAA as being non-political in nature. Birrell replied that "no person is being shadowed or watched in County Galway or elsewhere because he is a member of the Gaelic Athletic Association' (House of Commons 1910).

Birrell's answer, upon first reading, appears short and perfunctory, quickly replying and indeed dismissing O'Donnell's latent concern. However, more can be made of Secretary Birrell's reply than is immediately apparent. Birrell does not say that Kenny and the others are not being followed at all; merely that membership in the GAA was not grounds for being followed. Police in County Galway could very well have been following Mr Kelly, or anyone else, because of the government's perception of the GAA as being an associated part of the IRB. As was stated in the Dublin Castle report after the IRB takeover in 1886-87, the GAA was thought to be part of the 'physical force movement' in Ireland, and would therefore be subject to police scrutiny (Dublin Castle Records). Birrell's answer implies that while the British government in Ireland might not have considered membership in the GAA to be of sufficient grounds for police interest in itself, there was still a level of distrust of the upper echelons of the GAA leadership.

Indeed the leadership of the GAA unquestionably struggled with how to handle it existing as a nationalist body without appearing to be political in nature. The police report to Dublin Castle admitted that Michael Cusack had been 'quite honest in his original idea, which was to initiate a purely non-political association of athletes', but this was doomed from the start because of 'the utter impossibility of establishing amongst the general body of the Irish people a society of any kind which could be kept free from politics' (Dublin Castle Records). In 1886, two years after the foundation of the GAA, the so-called 'political clause' was added to the constitution, saying,

That the Gaelic Athletic Association shall not be used in any way to oppose any national movement, which has the confidence and support of the Irish people. (de Búrca 2000, 36)

The vague wording of the clause allowed both Home Rule and Fenian members to infer that the GAA supported their political views, which was subsequently used to great effect by Fitzgerald and other IRB sympathizers.

Nine years later, in 1905, on the occasion of his silver jubilee, Archbishop Croke wrote that, 'as far as he knew ... the Association was purely an athletic body and that alone. The members of the Association had taken sides in the recent political dispute, which was 
but natural' (de Búrca 2000, 104). At that year's convention, the 'first comprehensive constitution and rules of the GAA' were codified. In the constitution, Rule 2 clarified the apolitical nature of the GAA, reading:

That the Gaelic Athletic Association shall be a strictly non-political and unsectarian [sic] association. No political questions of any kind shall be raised at any of its meetings, and no club shall take part as a club in any political movement. (de Búrca 2000, 105)

While this new constitution advanced the official position of the GAA with regard to its political stance, it did little to dissuade the police from keeping a watchful eye on the GAA as a whole. Indeed police scrutiny would again fall on the GAA as the Irish Volunteers emerged as a dominant nationalist body.

Upon the formation of the Irish Volunteers, the Gaelic Athlete was quite vocal in its support and assertion that GAA members should join. The Gaelic Athlete was a weekly newspaper that styled itself 'the only journal in Ireland entirely devoted to Gaelic pastimes'. During World War I, the editorial staff of the Gaelic Athlete was unapologetic in their anti-British views, indeed nearly appearing pro-German at times. In one such instance, an editorial decried what the author felt was a 'pronounced Imperial tinge which has developed in the Irish atmosphere since the outbreak of the war.' Continuing, the author went on to state that 'our whole constitution is sternly opposed to any Jingo or pro-British tendency' (Editorial 1914, 137). As de Búrca notes, the Gaelic Athlete was not officially endorsed by the GAA, but it did have the support of many prominent Association figures and seemed to 'accurately reflect the mood of average members' (de Búrca 2000, 130).

With further regard to the Irish Volunteers, the Gaelic Athlete was a vocal supporter of its readers supporting the nationalist cause. A weekly article called 'Jots and Tittles' ran small news items, usually of a similar theme or content. In one edition of 'Jots and Tittles', it was relayed to the reader that 'over the Channel the present European situation has brought forth expression of opinion that the football field ought to be used as a recruiting ground for the Army' (Jots and Tittles 1914, 138). In a display of support for the Irish Volunteers, the article went on to say that 'a similar remark applies to Ireland in regard to our own Volunteer force' (Jots and Tittles 1914, 138). A more explicit appeal to aid the Volunteers was to appear in the very next edition of the paper.

In it, a large advertisement was published announcing that the Irish Volunteer Aid Association had begun organizing the Volunteer Military Medical Corps, under the auspices of the Irish Volunteers. The aim of the Medical Corps was to supply the Volunteers with 'proper Medical and nursing staffs, and adequate hospital and ambulance equipment' (Appeal for Help and Money 1914, 139). By 1915, the Gaelic Athlete was reporting that GAA involvement in the Irish Volunteers in Co. Kildare was so extensive that "nearly all the members of the GAA were identified with the "Volunteer movement" and that volunteer activities were interfering with the playing of Gaelic games' (Kildare 1915)

The most extreme position advocated by the Gaelic Athlete was that of the creation of rifle clubs, to be established, of course, under the auspices of the GAA. The idea for the rifle clubs emerged following a suggestion made by the Kerry County Board, the impetus for which was due 'to the growth of the military spirit in Ireland' (Editorial 1914, 142). The rifle clubs were to be organized in the same fashion as hurling and Gaelic football entities, with competition ranging from inter-club all the way to All-Ireland contests. The reason for the editorial staff believing the rifle clubs should be implemented under the organizational umbrella of the GAA was twofold. The first was that the rifle clubs would 
offer practical experience in the use of the rifle, and the 'material assistance' this in turn would present the Irish Volunteers. As such, this first reason was entirely a practical matter. Moreover, the newspaper's support for the Volunteers has been well established by this point. It only makes sense that the editorial staff would be in support of a programme to enhance the effectiveness of the Irish Volunteers. The second, more idealistic, reason was that the GAA was the only suitably 'nationalist' body capable of organizing such a competition. The logic was that if there was a demand for rifle clubs, that 'the GAA should be the body to cater for that demand, and not an alien body, or a body with no National motives' (Editorial 1914, 142). Again, the GAA is revealed as an organization with a firm nationalist orientation. The fear of the rifle clubs falling under the control of a body that was not nationalist in its outlook, or worse still a foreign one, required that the GAA be in control of any new development of the kind being discussed here. The GAA was founded on the grounds that it was to provide a means to promote and support Irish pastimes, in direct competition to those organizations that were British in origin, so no other body would do to run the proposed rifle clubs, which in turn would be effectively auxiliaries to the Irish Volunteers. Ultimately, of course, the rifle clubs never came into being.

In the direct aftermath of the Easter Uprising in 1916, the government of Great Britain held an official inquiry, the Royal Commission on the Rebellion in Ireland. A few choice quotes from high-ranking officials in the RIC and British Army reveal the attitude of those in power towards the Association. Sir Matthew Nathan, Under-Secretary for Ireland under Augustine Birrell, testified that he believed that the GAA had 'always been anti-British. They would not allow soldiers in uniform to attend their games' (Lieutenant-Colonel The Right Honourable Sir Matthew Hill, 3). Sir Neville Chamberlain, then Inspector General of the Royal Irish Constabulary, joined in with Nathan in condemning the GAA and its policy of refusing 'soldiers or sailors or police in joining in their games' (Sir Neville Chamberlain, Inspector General of the Royal Irish Constabulary, 3). Major Ivan Price, Director of Military Intelligence for Irish Command, believed that the Irish Volunteers had gained 'practically full control' of the GAA and Gaelic League (Major Ivan Price, 3). The connection between the GAA and Irish Volunteers had been well established and quite public. However, the GAA was not under the control of the Volunteers. Rather, as de Búrca suggests, the two bodies shared an 'informal but effective alliance' (de Búrca 2000, 133). Most of the information related to the commission regarding the GAA fell into two categories - displeasure with the ban on police and military and the belief that the GAA was controlled by the IRB, Sinn Féin or Irish Volunteers.

Throughout the earliest days of its creation, during one of the most pivotal moments in the move towards independence, the GAA had been characterized by the powers-that-be as an organization that was full of seditious IRB members, who worked hand in hand with the GAA to further the cause of independence. From here, it follows that if later historians accept the perspective put forward by the British government, but from the position that the GAA was a force for good in Irish society, that during this time the Association would have been an influential player in Irish life and its actions an essential part of the march towards independence.

However, this characterization is undoubtedly flawed. While it is indisputable that there was indeed overlap between the memberships of the two organizations, correlation does not imply causation. Rather, by drawing upon a few mere examples, it is possible to illustrate instead that the GAA provided a forum in which to gain experience in leading a complex group of individuals. It is this experience that served the men of the IRB, not the GAA itself. It is for this reason Murphy somewhat accurately characterized the GAA as 'the playground of the revolution' (Murphy 2009, 76). 


\section{Michael Collins}

When Michael Collins emigrated to London as a young man, he 'threw himself with all the enthusiasm of a healthy and vigorous youth' into the Geraldines Football Club (Béaslai 1926). Before long, Collins was elected secretary of the club at the tender age of 18 (Béaslai 1926). The effectiveness of Collins's diplomacy in sensitive matters can be seen with the handling of the payment of a debt to the proprietor of a pitch that was used by the Geraldines Club for its football matches. The incident began when the treasurer of the club, Mr Sullivan, mislaid the money for the rental of the pitch and neglected to tell anyone else in the club about this, presumably in an attempt to recover the money on his own without admitting to his error. The owner of the pitch, Mr A. Toley, threatened to no longer allow the Geraldines use of the grounds until the rent had been paid, a sum of $£ 3-16-6$. Collins then turned his attention to O'Sullivan, the club treasurer, in an attempt to resolve the matter. It was at this point that O'Sullivan finally admitted to having lost the money at the pitch. O'Sullivan worked to repay the club the lost funds. The careful handling of the situation by Collins led to a resolution satisfactory to almost all involved.

As secretary of the Geraldines, Collins had a responsibility to act in the best interests of the club. In the conflict with Mr Toley, Collins was at risk of losing the use of the pitch, which was so necessary to the continued survival of the club. However, Collins was able to assuage any slight perceived by Mr Toley to the point where Toley offered the club the use of a winter pitch. Without Collins's intervention, the club could have been faced with the loss of the pitch, or even legal action from Mr Toley as he sought compensation for his rent owed. However, the situation with the issue of pitch rentals would ultimately pale in comparison to the upheaval the London GAA would undergo at the end of the year, specifically in regard to the issue of the playing of foreign games.

Many of the London GAA members wished to play association football in addition to Gaelic football and hurling. However, the GAA had, since its inception, been adamantly against members playing or patronizing such so-called 'foreign' games, with those found to have done so subject to expulsion. Collins was steadfast in his refusal to allow the men of the Geraldines Club to partake in what he termed 'garrison games' (Coogan 1990, 16). Collins's report to his club at the end of the year was scathing in its indictment of the actions of the club:

An eventful half year has followed a somewhat riotous general meeting. Great hopes instead of being fulfilled have been rudely shattered ... Our internal troubles were saddening but our efforts in football and hurling were perfectly heartbreaking. In no single contest have our colours been crowned with success ... In hurling ... we were drawn to play five matches but, disgraceful to say, in only one did we field a full team. If members are not prepared to act more harmoniously together and more self-sacrificing together ... the club will soon have faced into inglorious and well-deserved oblivion. (Coogan 1990, 16)

Michael Collins was uncompromising in his view that foreign games were one of Britain's most effective agents in the 'peaceful penetration' of Irish society, and that under all circumstances there should be 'no soccer for Gaels' (Béaslai 1926, 16). By the end of the rift, only three clubs remained, one of them Collins's Geraldines (Coogan 1990). For Collins, the GAA was an important organization in the movement for Irish independence (Coogan 1990).

The commitment of the leadership of the Geraldine club to the ideals of Irish nationalism can be seen by a resolution passed by the team regarding the use of the Irish language. By a vote of 12 to 4 in favour, the club resolved for each member to obtain a copy of The Gaelic Athletic Annual so that they might 'learn the different terms in Irish used in Gaelic Football and Hurling thereby to carry into practice the ideal of our 
club - our national language on the field of play' (Michael Collins Collection: Geraldine Club Note).

The passion Collins carried for Gaelic games is readily evident from the dramatic speech he gave to his fellow Geraldines. His address also shows the general lackadaisical attitude of the other members of the club. Of the club's five hurling matches, only once did they manage to get enough players to field a team. Many members of the club were not nearly as emphatic in their support of it as was Collins. Collins' obvious belief in the GAA's role in supporting Irish nationalism is not reflected in the attitudes of the general membership. Even the ballot on the use of Irish language was not unanimous, and the amount of men who voted on the motion was just one more person than is needed to field a hurling team. Coming from a club with such strong beliefs in the tenets of Irish nationalism, Collins was a prime candidate to join more openly nationalistic and political bodies. Another member of the London GAA, Sam Maguire, would recognize this in Collins and recruit him into the IRB.

\section{Sam Maguire}

Maguire was a Corkman who had emigrated to London, where he played football for the Hibernian football club (Cronin 2005). As well as being a member of the London GAA, he also joined the Gaelic League and eventually the Irish Republican Brotherhood (Cronin 2005). Maguire remained at his job in the postal service in England until after the Irish War of Independence, working to intercept documents that may have been of interest to the military planners within the IRB. Maguire eventually returned to Ireland after the Irish Civil War, but could not keep his employment in the postal service after the government removed all former IRB members from civil service posts. Maguire eventually returned home to Cork where he died of tuberculosis in 1926 (Cronin 2005). However, Maguire is best remembered today as the namesake of the trophy given to the All-Ireland Gaelic football champions each year. Upon his return from London, Maguire saw himself as both an IRB and GAA member, adhering to neither pro- nor anti-treaty political parties. This left him to a position of being embraced by neither side, which resulted in turn to his dismissal from the civil service (Cronin 2005). However, as the GAA had always placed itself as a nationalist, but non-political, entity, Maguire was a perfect man to be honoured by a championship trophy.

\section{J.J. Walsh}

In addition to the GAA giving opportunities for direct leadership, it also gave leaders a chance to implement and test logistical measures designed to best run and organize large groups. The most appropriate example of using the GAA to implement such ideas is apparent in the work undertaken by J.J. Walsh, while a member of the Cork County Board. Walsh was a post office employee in Cork, as well as an influential GAA member. In his memoirs, Recollections of a Rebel, Walsh recounts that around 1902 the GAA was in decline in Cork, after 'all the educated and influential classes were switching over to alien games' (Walsh 1944, 16-17). Walsh and his cohorts saw an opportunity to bolster the falling ranks of the Cork GAA. 'In a short time', wrote Walsh,

we had organized hurling and football leagues, not only in the country, but also in the lanes and streets of the City and towns ... With this intensely organized instrument, war was declared on foreign games, which were made to absorb the shock so heavily that, one by one, soccer and rugby clubs began to disappear. $(1944,17)$ 
However, Walsh's grassroots organization of GAA clubs in Cork was still subject to oversight from the county board. Walsh felt that the board at the time was using methods that were 'out of date' and that his approach would be better if he and his men took 'on the whole responsibility for the GAA in the county' (1944, 17-18).

In 1909, Walsh was elected as chairman of the county board by a margin of 15 votes. Walsh divided his time between his job at the post office and his responsibilities with the county board. He wrote that he would often work on GAA matters until 'one or two a.m. and find myself at the Post Office counter at seven' $(1944,19)$. Walsh's experiences from working in the civil service allowed him to revolutionize the efficiency of the Cork GAA to the point that the county board had generated sufficient income to buy shares in the Great Southern Railway, which gave Walsh and the county board 'the necessary pull where travel facilities counted for a great deal' $(1944,18)$. The railways were a vital link for inter-county games, so the ability of the county board to influence the railways as shareholders, in addition to the clout exercised by the GAA, was a major boost to Cork. As would be seen after the Easter Uprising, restrictions on the use of the railways were to prove very detrimental to the abilities of the county boards to schedule matches against each other. In his book, Walsh wrote that soon county boards across the country, such as the Dublin County Board led by Harry Boland and Mick Crow, were emulating the techniques pioneered in Cork (1944).

However, unsurprisingly the British authorities in Ireland were not keen on Walsh's activities in Cork. After five years as chairman of the county board, Walsh was transferred to the post office in Bradford, England. The Gaelic Athlete immediately took up the issue of Walsh's transfer, decrying it as the 'first shot' in a 'campaign of terrorism' aimed at the Cork GAA (Editorial, 149). Its editorial described the chain of events that befell Walsh. First, he was subject to a compulsory transfer to the Bradford post office, for what they claimed was 'on account of that gentleman's National activities'. Walsh tendered his letter of resignation to the Cork County Board, which the board refused to accept. Instead, the county board adopted a resolution to petition the Postmaster-General to reinstate Walsh to his previous position in Cork. This resolution was presented to the Cork Corporation, of which Walsh was also a member. However, the Cork Corporation voted against the resolution. The Gaelic Athlete quoted the Corporation's decision as being 'a protest against [Walsh's] politics.' The editorial condemned Cork Corporation for what it called the 'intrusion upon the right of a free man in an alleged free country to hold what political views he wills'. GAA boards around the country passed resolutions in support of Walsh, but all to no avail (Editorial, 149).

Seven months on, in June 1915, J.J. Walsh had moved to Dublin and opened a shop at the corner of Blessington and Berkeley Streets on Dublin's north side. The Gaelic Athlete carried the news in an article entitled 'Rally Round, Boys!' (Rally Round, Boys, 182), urging its readers to show its support of 'his great services to the GAA' by purchasing goods from Walsh's new store. The article called for Walsh to receive a 'welcome from the Gaels of Dublin' by way of business for his new establishment. 'In patronizing that establishment,' the article continued, 'you are helping your own' (Rally Round, Boys, 182).

\section{Dick Fitzgerald}

Many people know Dick Fitzgerald as the famed footballer from Kerry, a man who won five All-Ireland medals and many more honours with his club side. Less well known is Fitzgerald's political involvement. Beginning as a member of the Gaelic League, Fitzgerald would become progressively more involved in the Kerry political scene as he 
aged. During the War of Independence and following the Civil War, Fitzgerald served on the Killarney urban council. At times, his political and sporting lives intertwined as he served on various GAA councils, from the board of his local club all the way to hearings of the organization's Central Council in Dublin.

Fitzgerald would assume his first leadership role with Dr Crokes when becoming club secretary in 1908 (Looney 2008). That year, Kerry won the Munster championship, but lost to Dublin in the All-Ireland Home Final. In 1911, Fitzgerald resigned his role as club secretary for Dr Crokes for an elevated role as a member of the club committee (Looney 2008). That year, during a particularly contentious match against Dr Crokes' main Kerry rivals, Tralee Mitchells, Fitzgerald and the rest of Dr Crokes left the pitch in protest. Because of a newly enacted rule that made any such walk-off a mandatory suspension - in an effort to curtail a growing number of such protests - Kerry were without the services of Fitzgerald and other Dr Crokes players for the county team. That year, Cork would go on to claim the All-Ireland title (Looney 2008). Despite these on-going problems, 1913 would be a banner year for Dick Fitzgerald. At a meeting of the Kerry County Board over which he presided, Fitzgerald moved that Kerry finally change their playing kits and formally adopt what would become their iconic green and gold hoops. Later in 1913, Kerry would defeat Wexford in the All-Ireland Final. Thanks in part to the small world of Irish politics and smaller world of the GAA, Harry Boland, the Dublin GAA leader and prominent IRB figure, refereed the final.

On 28 November 1913, Pádraig Ó Siochfradha, sometimes known by his nom de plume An Seabhac (The Hawk), formed a company of Irish Volunteers in Killarney. This formation of the Killarney Company took place at a meeting of the local Gaelic League, wherein the men in attendance, numbering approximately 40, unanimously voted to form the company (Bureau of Military History). Dick Fitzgerald was among the men in attendance, and would later be elected 2nd Lieutenant of the company (Bureau of Military History). Less than a month later, on 13 December 1913, Austin Stack, Chairman of the Kerry GAA Board, joined the Irish Volunteers at a meeting in Tralee.

\section{Easter 1916}

No coverage on the politics of Ireland in the movement towards independence would be complete without at least some considered mention of the happenings of Easter Sunday, 1916. The details of the exact goings on of the day, such as troop movements or buildings held by either side, do not fall within the scope of this article. Rather, brief note will be made about various roles played by GAA members during that pivotal week. Among those GAA members who were active throughout the Easter Rising were a handful of men who held key positions in the insurgency. The aforementioned Harry Boland was chairman of the Dublin GAA County Board at the time of the Easter Rising (Nolan 2000). In fact, Boland would find himself among the hundreds imprisoned after Easter Week. Other members of the GAA would also find themselves in pivotal roles in the fighting that took place, among them Frank Burke and Peadar Boyle. Frank Burke, who would go on to win two All-Ireland Senior Hurling and three All-Ireland Senior Football championships for Dublin, was a 2nd Lieutenant in the Irish Volunteers (Nolan 2000). Peadar Boyle, who served as quartermaster of the South Dublin Union Garrison, would go on to hold several important governmental positions, serving on Dublin Corporation, as Lord Mayor of Dublin, and as Fine Gael T.D (Nolan 2000).

The response of the British government after the Easter Uprising was swift. The rebellion was quelled within a week, many hundreds arrested, and its main leaders executed. 
As William Nolan notes, 'four of the executed leaders of the Easter Rising - Patrick Pearse, Con Colbert, Michael O'Hanrahan and Eamon Ceannt - were associated either in a players or administrative capacity within the GAA in Dublin' (Murphy 2009, 67).

Up until this point, this article has presented only a very small, purposive sample of evidence in support of its primary thesis concerning the comparatively modest role played by the GAA in the cause of forceful expressions of Irish nationalism. Such evidence could easily have been cherry-picked for its seeming ability to bolster the arguments presented here, where in actuality the small size of the sample is not, in truth, sufficient to reinforce any claims made either way. Seeking to augment these stories, this essay will delve briefly into some statistical work previously undertaken on the matter.

In fact, the figures on the number of members actively taking part in the Uprising further underpin Murphy's interpretation of the role of the GAA as a training ground, rather than active player, for Irish revolutionary politics. In The Gaelic Athletic Association in Dublin 1844-2000, William Nolan wrote that it was not so much membership of the GAA that motivated men and women to take up arms but rather membership of the Gaelic League' (Nolan 2000, 125). Figures in that same work show that many of the GAA clubs in Dublin had few or no members who partook in the Uprising. Murphy, citing figures from Walsh, figured that of the seventy GAA clubs in Dublin, thirty-two clubs had three or fewer members taking part, while 17 had no members involved in the Uprising (Murphy 2009). The actions of the few have influenced perceptions of the GAA as a major force in the events of Easter Week 1916. The high profile members of the GAA who did take up arms invited the attention of the British authorities upon the organization, even though, as has been made clear, a majority of clubs in Dublin had few or no members who took part in the Uprising. This attention has passed on to the histories of the GAA, where a disproportionate amount of responsibility has been placed on the GAA for the events of Easter Week.

Peter Hart produces similar figures for the lack of involvement of the GAA in Irish Republican Army activities. In his publication 'The Geography of Revolution in Ireland', Hart compares incidences of IRA violence and membership in the GAA and concludes that 'there is little other evidence to suggest a strong link between [the GAA and IRB]'. The correlation coefficient of such a relationship stands at only 0.06, suggesting no correlation at all between the two otherwise independent factors. Hart then cites J.J. O'Connell's assertion that 'it was a fact that the Volunteers did not receive from the GAA the help they expected' (Hart 1997, 169).

\section{Conclusion}

Dominant historiography has treated the GAA as a major force in Irish independence. Authors like Mandle and de Búrca have equated the particular nationalism of the GAA with the movement for Ireland's campaign for sovereignty. High-profile GAA members who also were involved in revolutionary activities have reinforced this perception still further, both in popular thought and academic research. Gaelic games provided men like Michael Collins with practical experience in leadership and organizational skills, which has erroneously been extrapolated into the belief that the GAA was an active organ for independence. Merely having revolutionaries in its ranks does not itself make the GAA a revolutionary body. While the GAA contained a small number of men who would fight and indeed die for Ireland, the association and its members were not taking up arms on any grand, coordinated scale. The decision to participate in the events of Easter Week, for example, was an entirely personal one, not one dictated by the GAA and it is the important 
distinction that must continue to be highlighted in any examination of the association either side of the dawn of the twentieth century.

\section{Disclosure statement}

No potential conflict of interest was reported by the authors.

\section{References}

"Appeal for Help and Money". Gaelic Athlete, vi, no. 139. August 29, 1914.

Béaslai, P. 1926. Michael Collins and the Making of a New Ireland. Vol. 2. London: Harrap.

Bureau of Military History. Witness Statement of Michael Spillane and Michael J. O'Sullivan, WS 132.

Coogan, T. 1990. Michael Collins: A Biography. London: Hutchison.

Cronin, M. 2005. "Sam Maguire: Forgotten Hero and National Icon." Sport in History 25 (2): 189-205. doi:10.1080/17460260500186744.

de Búrca, M. 2000. The GAA: A History. Dublin: Gill \& Macmillan.

Dublin Castle Records. The Political Aspect of the Gaelic Athletic Association, CO904/16. National Archives, London.

Fitzpatrick, D. 1978. “The Geography of Irish Nationalism 1910-1921.” Past \& Present 78 (1): 113-144. doi:10.1093/past/78.1.113.

"Editorial". Gaelic Athlete, iv, 137. August 15, 1914.

"Editorial". Gaelic Athlete, v, 142. September 19, 1914.

"Editorial". Gaelic Athlete, vi, 149. November 7, 1914.

Hart, P. 1997. "The Geography of Revolution in Ireland 1917-1923." Past \& Present 155 (1): 142-176. doi:10.1093/past/155.1.142.

House of Commons. 1910. "Gaelic Athletic Association Meetings (County Galway)." Sessional Papers: Oral Answers to Questions 16: 1699-1700.

"Jots and Tittles". Gaelic Athlete, iv 138. August 22, 1914.

"Kildare". Gaelic Athlete, vii, no. 158. January 9, 1915.

"Lieutenant-Colonel The Right Honourable Sir Matthew Hill". Minutes of Evidence Given before the Royal Commission on the Rebellion in Ireland, 3, [Cd. 8311], H.C. 1916, xi.

Looney, T. 2008. Dick Fitzgerald: King in a Kingdom of Kings. Dublin: Currach Press.

"Major Ivan Price". Minutes of Evidence Given before the Royal Commission on the Rebellion in Ireland, p. 3, [Cd. 8114], H.C. 1916, xi, 242.

Mandle, W. F. 1987. The Gaelic Athletic Association and Irish National Politics 1884-1924. Dublin: Gill and Macmillan.

Michael Collins Collection. "Geraldine Club Note (undated)." P123/36 UCD Archives.

Murphy, W. 2009. "The GAA During the Irish Revolution 1913-23." In The Gaelic Athletic Association 1884-2009, edited by M. Cronin, W. Murphy, and P. Rouse, 61-76. Dublin: Irish Academic Press.

Nolan, W., ed. 2000. The Gaelic Athletic Association in Dublin 1884-2000. Dublin: Geography Publications.

"Rally Round, Boys!". Gaelic Athlete, vii, 182. June 26, 1915.

Ranelagh, J. 1983. A Short History of Ireland. Cambridge: Cambridge University Press.

"Sir Neville Chamberlain, Inspector General of the Royal Irish Constabulary". Minutes of Evidence Given Before the Royal Commission on the Rebellion in Ireland, 3, [Cd. 8311], H.C. 1916, xi.

Walsh, J. J. 1944. Recollections of a Rebel. Tralee: The Kerryman. 